\title{
Application of Fine Management on Construction Unit Investment of Construction Project in University
}

\author{
Haoming Peng and Xinhua Xiong \\ Hunan Institute of Technology, Hengyang, Hunan Province, China
}

\begin{abstract}
This paper discusses the methods to implement the investment management efficiently and finely with personal engineering practice. The methods includes constructing the investment information platform of construction project, building project money payment management card, building completion summary system of project investment management, forming first trial document of completion settlement and summary report of project investment.
\end{abstract}

Keywords-investment objective management; project investment information platform; summary of investment management completion

\section{INTRODUCTION}

For construction project in university, the management objectives of construction stage include investment, quality and progress. While the university is investing party, the investment management objectives of construction stage is adjusting the happened and impendent deviation, controlling the production cost in the planned cost by plan, coordination, limitation and supervisory control ${ }^{[1]}$. The management departments in university include capital construction, audit, financial, supervision, and so on. For construction stage, there exist many effect factors, such as the policy of governmental authorities, requirement of consumer, geological condition and abnormal project progress. Besides, there exist the parallel operation of different management departments and deficiency of collaborative related system. Because of these phenomena, these problems as confusion of investment cost, postponed payments, unpredictable increased investment cost exist. This paper discusses the methods to implement the investment management efficiently and finely with personal engineering practice.

\section{Fine MANAGEMENT ON CONSTRUCTION UNIT INVESTMENT OF CONSTRUCTION PROJECT}

In modern management theory, there are three levels, the first is standardization, the second is refinement, and the third is personalization. Fine management means embodiment and specification of management responsibility, the essential meaning of fine management is to decompose, refine and implement the strategic target $\mathrm{l}^{[2]}$, and the maneuverability is obtained.

Thus, it has important practical significance to implement investment management of construction stage with scientific management mode and study the operable fine management measures.
A. Constructing the Investment Information Platform of Construction Project, Building Project Money Payment Management Card

Information management, contract management and coordination management are the three methods of construction stage. It is necessary to construct the network information platform concerning the investment composition of whole construction stage construction process. The network information platform is consisted of total investment composition, advanced payment and rebate of construction project application, contract cost composition, advanced payment and rebate of construction project, performance security refund plan, project payment disbursement schedule, project change, contract settlement, and so on ${ }^{[3]}$. At the same time, according to the scientific research funds card, the project money payment management card can be built. With information platform and management card, the cost is clear, which is helpful for such department as capital construction, audit, financial, supervision to control the usage of investment, and to forbid the delay or overpayment of project money.

TABLE I. ADVANCED PAYMENT AND REBATE OF CONSTRUCTION PROJECT APPLICATION

\begin{tabular}{|l|l|l|l|l|l|}
\hline Type & $\begin{array}{l}\text { Measure expense of } \\
\text { safe and civilized } \\
\text { construction } \\
\text { peasant } \\
\text { workers } \\
\text { salary }\end{array} \quad$ of & $\begin{array}{l}\text { Keeping } \\
\text { clear fee }\end{array}$ & $\begin{array}{l}\text { Other } \\
\text { fee }\end{array}$ & $\begin{array}{l}\text { person } \\
\text { liable }\end{array}$ \\
\hline $\begin{array}{l}\text { Amount } \\
\text { (yuan })\end{array}$ & & & & & \\
\hline $\begin{array}{l}\text { Advanced } \\
\text { payment } \\
\text { time }\end{array}$ & & & & & \\
\hline $\begin{array}{l}\text { Rebate } \\
\text { requirement }\end{array}$ & & & & & \\
\hline Rebate time & & & & & \\
\hline
\end{tabular}


TABLE II. PROJECT PAYMENT DISBURSEMENT SCHEDULE AND ACTUAL PAYMENT

\begin{tabular}{|c|c|c|c|c|c|c|c|}
\hline \begin{tabular}{|l|} 
serial \\
number
\end{tabular} & \begin{tabular}{|l} 
project \\
progress
\end{tabular} & $\begin{array}{l}\text { disburse } \\
\text { ment } \\
\text { schedule }\end{array}$ & \begin{tabular}{|l|} 
amount \\
payable
\end{tabular} & \begin{tabular}{|l|} 
Actual \\
payable
\end{tabular} & \begin{tabular}{|l|} 
Paym \\
ent \\
time
\end{tabular} & remark & \begin{tabular}{|l|} 
person \\
liable
\end{tabular} \\
\hline 1 & \begin{tabular}{|l|} 
foundation \\
engineering
\end{tabular} & & & & & & \\
\hline 2 & main works & & & & & & \\
\hline 3 & \begin{tabular}{l|} 
decoration \\
engineering
\end{tabular} & & & & & & \\
\hline 4 & $\begin{array}{l}\text { completion } \\
\text { acceptance }\end{array}$ & & & & & & \\
\hline 5 & $\begin{array}{|ll|}\text { fire control } \\
\text { acceptance }\end{array}$ & & & & & & \\
\hline 6 & $\begin{array}{l}\text { project } \\
\text { settlement }\end{array}$ & & & & & \begin{tabular}{|l|} 
Rebate \\
the \\
advanced \\
payment \\
and \\
advanced \\
payment \\
of project \\
payment
\end{tabular} & \\
\hline 7 & $\begin{array}{l}\text { First quality } \\
\text { assurance }\end{array}$ & & & & & & \\
\hline 8 & $\begin{array}{l}\text { Second } \\
\text { quality } \\
\text { assurance }\end{array}$ & & & & & & \\
\hline
\end{tabular}

B. Constructing Project Change Program with "Submit-

Perambulation-Report-Design-Audit-Approval-Filing-Imp lement"

During the project construction process, because of revision of national current standard, abnormality of project geology and change of using function, the project content may be changed, which causes the increase of investment. Thus, to ensure the necessary of project change and the seriousness of fund utilization, the program with "submitperambulation-report-design-audit-approval-filing-implement " must be constructed. The concrete suggestions are as follows:

Submit: based on the function variation, the user unit submits application to unified specialized department and leader, and commits the paper report approved to the capital construction department. Construction unit commits the administrative instrument of project change approved by administration department or abnormality report of project geology to the capital construction department.

Perambulation: based on the file and report committed, the capital construction department cooperated with other department of audit, financial, and supervision, or with the unit of construction, design, investigation, and supervision, investigates the change on site, and discusses the necessary and feasibility of project change. Then, the change fee is estimated by unit of design, construction, investigation, and supervision, summarized by capital construction department, and signed by audit, financial, supervision department.

Report: reports the change fee to school leaders and corresponding meetings.

Design: after approved by school leaders and corresponding meetings, the original design unit designs the change, and provides design estimate.

Audit: based on the design change drawings and design estimate, the audit department prepares construction budget.

Approval: reports the construction budget of project change to school leaders and corresponding meetings.

Filing: files the approval conclusion and sends to information platform.

Implement: construction unit implements based on the design change drawings.

C. Building Completion Summary System of Project

Investment Management, Forming First Trial Document of Completion Settlement and Summary Report of Project

Investment

Summary system of project investment is used to inspect and evaluate the project investment comprehensively, and judge whether the investment objectives be achieved or not. The system is consisted of two steps:

1) First trial document of completion settlement:

This document is compiled by the capital construction department, and is based on the completion settlement files and completion report. The document illustrates the fee of main works, decoration, water-electricity and fire protection, and other appurtenant works from the contract business bid, bill of quantities, difference adjustment of materials and project change. The document is committed to the audit department.

2) Summary report of project investment:

after completion settlement, the summary report is compiled by department of audit, capital construction, financial and supervision, which is used to inspect and evaluate the project investment comprehensively, and judge whether the investment objectives be achieved or not. And provides depth analysis and experience summary.

\section{CONCLUSION}

This paper discusses the methods to implement the investment management efficiently and finely with personal engineering practice. The methods are as follows:

1) Constructing the Investment Information Platform of Construction Project, Building Project Money Payment Management Card for the first time. At the same time, according to the scientific research funds card, the project money payment management card can be built. With information platform and management card, the cost is clear.

2) Constructing the "submit- perambulation-reportdesign-audit-approval-filing-implement” program to ensure the necessary of project change and the seriousness of fund utilization. 
3) Building completion summary system of project investment management, forming first trial document of completion settlement and summary report of project investment for the first time. With which inspects and evaluates the project investment comprehensively, and judges whether the investment objectives be achieved or not. And provides depth analysis and experience summary.

\section{REFERENCES}

[1] Ding shizhao. Project management. China architecture $\&$ building press, 2014

[2] Liu Hui. "definition and operation of fine management" Enterprise reform and management, 2007(4):15-16

[3] Department of capital construction. management data of capital construction of Hunan Institute of Technology, 2017 